\title{
Physicochemical characterization of agro-industrial residues for second-generation ethanol production
}

Caracterização físico-química de resíduos agroindustriais para produção de etanol de segunda geração

Caracterización fisicoquímica de residuos agroindustriales para la producción de etanol de segunda generación

Igor Vieira Evangelista ORCID: https://orcid.org/0000-0002-2864-441X Federal University of Uberlândia, Brazil E-mail: igorevangelista_vieira@ hotmail.com

Adam Gonçalves Arruda ORCID: https://orcid.org/0000-0002-2956-1691 Federal University of Uberlândia, Brazil E-mail: adam.arruda@outlook.com

Larissa Soares de Menezes ORCID: https://orcid.org/0000-0002-7179-777X Federal University of Uberlândia, Brazil

E-mail: larissasoaresmenezes@hotmail.com

Janaína Fischer ORCID: https://orcid.org/0000-0002-7563-4097 University of Passo Fundo, Brazil E-mail: janaffischer@hotmail.com

Carla Zanella Guidini

ORCID: https://orcid.org/0000-0002-6562-8160 Federal University of Uberlândia, Brazil E-mail: carlazguidini@ufu.br

\begin{abstract}
Ethanol production from renewable sources, such as lignocellulosic materials, is already underway in several countries. The interest in the technology stems from concerns about global warming and the environmental impacts of solid waste disposal. Moreover, the conversion of agro-industrial wastes into ethanol is a value-adding strategy. This study aimed to evaluate the physicochemical characteristics of three lignocellulosic materials - rice straw bran, sugarcane bagasse, and corn peel bran - and determine, on the basis of these analyses, their suitability as feedstocks for second-generation ethanol production. Physicochemical characterization included the determination of particle size, moisture, ash, total solids, water activity, crude fat, protein, total extractives, soluble and insoluble lignin, holocellulose, cellulose, hemicellulose, and total carbohydrates. Rice straw bran is composed of $38.33 \%$ cellulose and $19.73 \%$ hemicellulose, sugarcane bagasse is composed of $27.09 \%$ cellulose and $5.61 \%$ hemicellulose, and corn peel bran is composed of $55.75 \%$ cellulose and $12.93 \%$ hemicellulose. The characterization showed the high concentration of cellulose in the residue of the corn peel bran. The results indicate that the three biomasses are suitable raw materials for biofuel production.
\end{abstract}

Keywords: Lignocellulosic; Rice straw bran; Sugarcane bagasse; Corn peel bran; Bioethanol.

\section{Resumo}

A produção de etanol a partir de fontes renováveis, como materiais lignocelulósicos, já está sendo produzido em vários países. O interesse pela tecnologia decorre da preocupação com o aquecimento global e os impactos ambientais do descarte de resíduos sólidos. Além disso, a conversão de resíduos agroindustriais em etanol é uma estratégia de agregação de valor. Este estudo teve como objetivo avaliar as características físico-químicas de três materiais lignocelulósicos - farelo de palha de arroz, bagaço de cana-de-açúcar e farelo de casca de milho - e determinar, com base nessas análises, sua adequação como matéria-prima para a produção de etanol de segunda geração. A caracterização físico-química incluiu a determinação de granulometria, umidade, cinzas, sólidos totais, atividade de água, gordura bruta, proteína, extrativos totais, lignina solúvel e insolúvel, holocelulose, celulose, hemicelulose e carboidratos totais. O farelo da palha de arroz é composto por 38,33\% de celulose e 19,73\% de hemicelulose, o bagaço de cana é composto por $27,09 \%$ de celulose e $5,61 \%$ de hemicelulose e o farelo de casca de milho é composto por $55,75 \%$ de celulose e $12,93 \%$ de hemicelulose. A caracterização evidenciou a alta concentração de celulose no 
resíduo do farelo da casca do milho. Os resultados indicam que as três biomassas são matérias-primas adequadas para a produção de biocombustíveis.

Palavras-chave: Lignocelulósicos; Farelo de palha de arroz; Bagaço de cana-de-açúcar; Farelo de casca de milho; Bioetanol.

\section{Resumen}

La producción de etanol a partir de fuentes renovables, como los materiales lignocelulósicos, ya está en marcha en varios países. El interés en la tecnología proviene de las preocupaciones sobre el calentamiento global y los impactos ambientales de la eliminación de desechos sólidos. Además, la conversión de desechos agroindustriales en etanol es una estrategia de valor agregado. Este estudio tuvo como objetivo evaluar las características fisicoquímicas de tres materiales lignocelulósicos — salvado de paja de arroz, bagazo de caña de azúcar y salvado de cáscara de maíz- y determinar, a partir de estos análisis, su idoneidad como materia prima para la producción de etanol de segunda generación. La caracterización fisicoquímica incluyó la determinación del tamaño de partícula, humedad, cenizas, sólidos totales, actividad de agua, grasa cruda, proteína, extractos totales, lignina soluble e insoluble, holocelulosa, celulosa, hemicelulosa y carbohidratos totales. El salvado de paja de arroz está compuesto por un 38,33\% de celulosa y un 19,73\% de hemicelulosa, el bagazo de caña de azúcar está compuesto por un 27,09\% de celulosa y un 5,61\% de hemicelulosa, y el salvado de cáscara de maíz está compuesto por un 55,75\% de celulosa y un 12,93\% de hemicelulosa. La caracterización mostró la alta concentración de celulosa en el residuo del salvado de cáscara de maíz. Los resultados indican que las tres biomasas son materias primas adecuadas para la producción de biocombustibles.

Palabras clave: Lignocelulósicos; Salvado de paja de arroz; Bagazo de caña de azúcar; Salvado de cáscara de maíz; Bioetanol.

\section{Introduction}

Agro-industries generate large volumes of waste and spend considerable amounts of money with solid waste disposal. The conversion of agro-industrial residues into high added value products, such as second-generation ethanol, is a solution to this costly problem (Paula et al., 2011; Sudha et al., 2015). However, plant residues are complex matrices, and thorough characterization is required to determine their suitability as raw materials for bioethanol production (Mitra, 2015).

Brazil has a large agricultural sector and produces tones of agro-industrial residues per year, the majority of which is used as animal feed or for household energy production in cogeneration systems. Nevertheless, there are concerns about the environmental impacts associated with the improper disposal of agro-industrial wastes (Santos et al., 2012). New policies and procedures have been adopted for handling and processing solid wastes with the aim of recovering, recycling, and converting wastes into value-added products (Gombert \& Maris, 2015; Jan et al., 2017).

According to FAO, the United States and Brazil remain the two largest ethanol producers, the world biofuel projections for ethanol from 119.3 (2016) to 128.4 million litres (2025). A report, Biofuels Annual, by the United States Department of Agriculture (USDA) estimated that Brazilian ethanol production in 2020 at 31.35 billion liters, a decrease of 16 percent relative to the revised figure for 2019 (37.38 billion liters), mainly because sugar-ethanol plants are diverting more sugarcane towards sugar production.

Second-generation ethanol is produced from agro-industrial biomass (Raele et al., 2014). These lignocellulosic materials are abundant and low cost. Unlike sugar- and starch-based substrates, lignocellulosic materials can be used for ethanol production without impacting food supplies (Bahmani et al., 2016). Among the components mainly by cellulose, hemicellulose and lignin, due to the recalcitrant structure they need more process steps to release access to carbohyd rates. Industries and researchers across the world have been faced with the challenge of reducing ethanol production costs (UDOP, 2017).

This study aimed to determine the physicochemical properties of three agro-industrial residues - rice straw bran, sugarcane bagasse, and corn peel bran - and evaluate their potential as raw materials for second-generation ethanol production. 


\section{Material and Methods}

Biomass samples were kindly donated by Brazilian agro-industries. Corn peel bran, a by-product of starch processing, was provided by Cargill Incorporated (Uberlândia-MG, Brazil). Steam-exploded sugarcane bagasse was donated by the Sugarcane Technology Center - CTC (Piracicaba - SP, Brazil). And ground rice straw bran was supplied by Cocal Ltda (Uberlândia-MG, Brazil). The samples did not require any pre-treatment before analysis, according to National Renewable Energy Laboratory (NREL) guidelines. All analyses were performed in triplicate. In the Figure 1 the spect of the agroindustry residues are presented. In the present study, methodological supports were based on Pereira et al. (2018). Thus, materials and methods used are set out below.

Figure 1 - Aspect of the agroindustriais residues of (a) rice straw bran, (b) sugarcane bagasse and (c) corn peel bran, respectively.

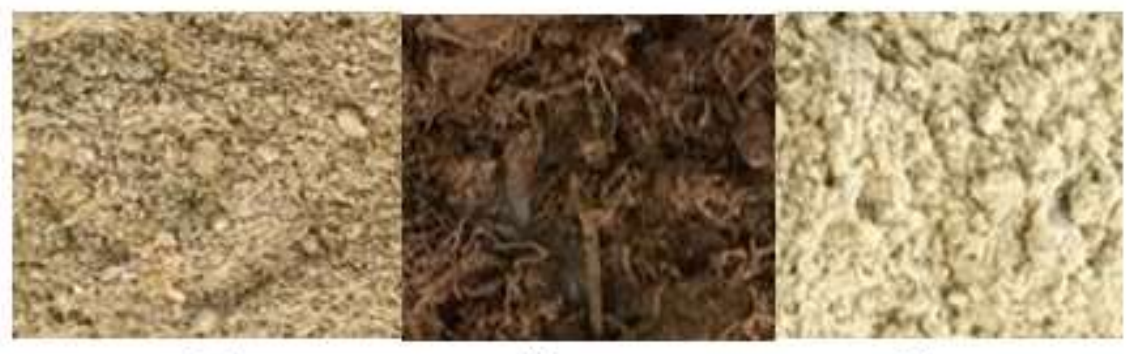

(a)

(b)

(c)

Source: Authors.

\subsection{Particle Size Analysis}

The particle size distribution is used to characterize the particle size of a material, since materials with identical average diameters can have different distributions. Particle size distribution (granulometric distribution) was determined by sieving 50 g of sample through 10 to 35 mesh $(1.68 \mathrm{~mm}-420 \mu \mathrm{m})$ Tyler standard sieves placed on a vibratory sieve shaker for 10 to 20 min and until a constant mass determined by analytical balance. After sieving, the mass of material retained in each sieve was determined (Gomides, 1997).

\subsection{Determination of Extractives}

To avoid interferences with later analytical steps, it is necessary to remove non-structural material from biomass prior to analysis. Thus, the content of extractives in the biomass samples was determined by Soxhlet extraction according to the NREL method (Sluiter et al., 2008a). Approximately $4.0 \mathrm{~g}$ of sample were placed in a round-bottom flask on a heating mantle. Successive extractions were performed for $6 \mathrm{~h}$ with ultrapure water and for $16 \mathrm{~h}$ with anhydrous ethanol using $190.0 \mathrm{~mL}$ of solvent. Was adjusted the heating mantles to provide a minimum of 4-5 siphon cycles per hour to water and of 6-10 siphon cycles per hour to ethanol extractions. The solvent was evaporated, separated and stored, at the end of each extraction. The extracted solids were transferred to a cellulose paper filter in a Buchner funnel and washed with approximately $100.0 \mathrm{~mL}$ of anhydrous ethanol. The samples were oven dried for $24 \mathrm{~h}$ at $40 \pm 2{ }^{\circ} \mathrm{C}$, and the total extractives content was calculated. 


\subsection{Determination of Structural Carbohydrates and Lignin}

The constituents the biomass samples, carbohydrates and lignin, must be measured as part of a comprehensive biomass analysis. Carbohydrates can be structural or non-structural. Structural carbohydrates are bound in the matrix of the biomass, while non-structural carbohydrates can be removed using extraction or washing steps.

Structural carbohydrates, cellulose and hemicellulose, and lignin were analyzed following the NREL method (Sluiter et al., 2012). Extractives-free biomass samples $(0.25 \mathrm{~g})$ were placed in test tubes and received the addition of $3.0 \mathrm{~mL}$ of $72 \%$ $(\mathrm{m} / \mathrm{m})$ sulfuric acid. The system was incubated in a water bath at $30 \pm 2^{\circ} \mathrm{C}$ for one hour. Manual agitation was performed every $5 \mathrm{~min}$. Stirring is essential to ensure even acid to particle contact and uniform hydrolysis. The mixture was diluted with 80.0 $\mathrm{mL}$ of ultrapure water, autoclaved for one hour at $121^{\circ} \mathrm{C}$. After cooling the hydrolyzates near room temperature, filtered through a sintered glass crucible, with previously measured mass in an analytical balance, using a vacuum pump. The sample retained in the crucible was oven dried at $105 \pm 2^{\circ} \mathrm{C}$ until a constant mass for the determination of the acid insoluble lignin fraction.

Acid soluble lignin was determined in the filtrate, well as carbohydrates. To acid soluble lignin, a $1.0 \mathrm{~mL}$ aliquot was diluted with ultrapure water in $100.0 \mathrm{~mL}$ flasks, to bring the absorbance into the range of $0.7-1.0$, and absorbance was determined by ultraviolet spectrophotometry at $240 \mathrm{~nm}$. The acid soluble lignin content was calculated according to Equations (1) and (2):

\%Acid Soluble Lignin $=\frac{A \times V_{\text {filtrate }} \times D}{\varepsilon \times m \times p}$

$D=\frac{V_{\text {sample }}+V_{\text {filluting solvent }}}{V_{\text {sample }}}$

Where $A$ is the UV-Vis absorbance of the sample at appropriate wavelength, $V_{\text {filtrate }}$ is the volume of the filtrate, $D$ is the dilution factor, $\varepsilon$ is the absorption coefficient of the sample, $m$ is the mass of the sample (mg), and $p$ is the pathlength of the cuvette $(\mathrm{cm})$.

The hydrolyzed liquor was utilized to determination carbohydrates, was transferred an approximately $20 \mathrm{~mL}$ aliquot of each liquor to a $50 \mathrm{~mL}$ Erlenmeyer flask, and neutralized with calcium carbonate to $\mathrm{pH}$ 5.5-6.0, then decant and filtered whit $0.22 \mu \mathrm{m}$ filter. This filtrate was used for the determination of sugars by high performance liquid chromatography (HPLC) on a Shimadzu LC-20A Prominence chromatograph equipped with Supelcogel K column and a refractive index detector. The mobile phase was $15 \mathrm{mM}$ dibasic potassium phosphate, the flow rate was set at $0.5 \mathrm{~mL} / \mathrm{min}$, the oven temperature was set at 85 ${ }^{\circ} \mathrm{C}$, and the injection volume was $10 \mu \mathrm{L}$. The sugar content was determined using calibration standards and Equation (3):

\%Sugar $=\left(\frac{C_{\text {HPLe }} \times \text { F }}{m} V_{\text {filtrate }}\right) \times 100$

where $C_{\mathrm{HPLC}}$ is the sugar concentration determined by HPLC $(\mathrm{mg} / \mathrm{mL})$, F is the conversion factor of 0.88 for C-5 sugars (xylose and arabinose) or the correction factor of 0.90 for C-6 sugars (glucose, galactose, and mannose), $V_{\text {filtrate }}$ is the volume of filtrate, and $m$ is mass of sample in milligrams free extractives.

\subsection{Holocellulose, $\alpha$-cellulose and hemicellulose, determination}

The holocellulose is generally used to refer to carbohydrates totals present in a plant cell. The $\alpha$-cellulose indicates na undegraded, higher molecular mass cellulose content in pulp; the $\beta$-cellulose indicates a degraded cellulose, and the $\gamma$-cellulose consists mainly of hemicellulose (Ranby, 1952; Ziaie-Shirkolaee et al., 2007). The main technique used in the determination of 
holocellulose consists of the oxidation of lignin in an acidic medium, and for the determination of the $\alpha$-cellulose content is the determination of the holocellulose fraction that is not dissolves in the solution of sodium hydroxide (Morais et al., 2010).

The experimental procedure was an adaptation by Morais et al. (2010), holocellulose were prepared by treatment of the biomass with sodium chlorite under acidic conditions, extractives-free sample $(4.0 \mathrm{~g})$ was added to a $1.0 \mathrm{~L}$ Erlenmeyer flask containing $110.0 \mathrm{~mL}$ of ultrapure water, and added $3.0 \mathrm{~mL}$ of concentrated glacial acetic acid, $22.0 \mathrm{~mL}$ of sodium acetate $20 \%$, and $9.0 \mathrm{~mL}$ de sodium chlorite $(40 \%)$. The system was heated at $75 \pm 2{ }^{\circ} \mathrm{C}$ under constant stirring for $1 \mathrm{~h}$, and Erlenmeyer flask capped with a vapor collection system. The reagents were added slowly until a white precipitate was formed. The precipitate was cold and filtered in a system containing sintered glass funnel connected in a kitasato flask and vacuum pump. The filter mass was previously measured in an analytical balance. The precipitate collected in the funnel washed with 500.0 $\mathrm{mL}$ of ultrapure water until the proximity of neutrality, after whit $10.0 \mathrm{~mL}$ of acetone, and another washing with ultrapure water. The funnel- holocellulose was oven dried at $105 \pm 2{ }^{\circ} \mathrm{C}$ for $18 \mathrm{~h}$, until constant mass, and determined the mass the holocellulose.

$\alpha$-Cellulose and hemicellulose were determined in the powder obtained for analysis of holocellulose. The sample, $1.0 \mathrm{~g}$, was placed in a mortar and added $15.0 \mathrm{~mL}$ of $17.5 \%(\mathrm{~m} / \mathrm{v})$ sodium hydroxide solution and allowed to rest for $2 \mathrm{~min}$. Then, the sample was crushed for $8 \mathrm{~min}$, received the addition $40.0 \mathrm{~mL}$ of ultrapure water, and transfer the content, quantitatively, to the sintered glass funnel (the mass was previously measured) and precipitate washed with ultrapure water until the proximity of neutrality. Posteriorly was oven dried at $105 \pm 2{ }^{\circ} \mathrm{C}$ for $18 \mathrm{~h}$ until constant mass. Was determined the mass the resulting material, and the data were used to calculate the content of $\alpha$-cellulose and hemicellulose.

\subsection{Determination of Total Solids}

Biomass can contain large and varying amounts of moisture, which can change quickly when exposed to air. Thus, the results of chemical analyses of biomass samples are typically reported on a dry mass basis. Total solids determination was carried out according to Sluiter et al. (2008b). Prior to the analysis, aluminum dishes were oven dried at $105 \pm 2{ }^{\circ} \mathrm{C}$ for $4 \mathrm{~h}$. Then, $0.5 \mathrm{~g}$ of sample was uniformly spread onto a dish and placed in an infrared moisture analyzer set at $105 \pm 2{ }^{\circ} \mathrm{C}$. The sample was analyzed until the change in mass was less than $0.05 \%$ per minute, defined as constant mass. Moisture content was calculated from the percentage of total solids according to Equation (4):

$\%$ Moisture $=100 \%-\%$ Total solids

\subsection{Determination of Water Activity (aw)}

The water activities $\left(a_{w}\right)$ indicates the intensity of the forces that join the water with other componentes and, consequently, a water available for the growth of microorganisms, so that they can carry out reactions and biochemical (Ordoñez et al., 2005). Water activity was determined in $0.5 \mathrm{~g}$ of sample using a water activity meter (AQUALAB). The ambient temperature was $28.7^{\circ} \mathrm{C}$.

\subsection{Ash determination}

The amount of inorganic material in biomass, structural or extractable, should be measured as part of the total composition. Structural ash is inorganic material that is bound in the physical structure of the biomass. Extractable ash is inorganic material that can be removed by washing or extracting the material. These can be the result of soil remaining in the biomass. 
Thus, the ash content was determined according to Sluiter et al. (2008c). Ashing crucibles containing $2.0 \mathrm{~g}$ of sample were kept on a heating sytem until smoke was no longer produced. The crucibles were placed in a desiccator containing desiccant to cool. Were, then calcined in a muffle furnace at $575 \pm 5^{\circ} \mathrm{C}$ for $24 \mathrm{~h}$. After cooling, was determined mass the crucibles, and the ash content was calculated using Equation (5).

$$
\text { \%Ash }=\frac{\text { Sample mass before calcination }- \text { Sample mass aftercalcination }}{\text { Sample mass before calcination }} \times 100
$$

Ash- The inorganic residue left after dry oxidation at $575^{\circ} \mathrm{C}$.

\subsection{Protein determination}

Biomass used as a feedstock for conversion to fuels contain protein and other nitrogen containing materials. The Kjeldahl method is widely used to measured nitrogen content of the biomass sample and the protein content is estimated using an appropriate Nitrogen Factor (NF). Thus, protein content was determined according to Hames et al. (2008) by the Kjeldahl method. The method consists of three steps: digestion, distillation, and titration. In the first step, $1.0 \mathrm{~g}$ of homogenized sample, $1 \mathrm{~g}$ of catalyst, and $5 \mathrm{~mL}$ of concentrated sulfuric acid were added to Kjeldahl tubes. The tubes were placed in a block digester at ambient temperature $\left(25 \pm 2{ }^{\circ} \mathrm{C}\right)$. The temperature was increased by $50{ }^{\circ} \mathrm{C}$ every 20 min until it reached $400 \pm 5{ }^{\circ} \mathrm{C}$. The digestion end-point was defined when the solution became liquid and translucent, and the brownish smoke stopped being released. The tubes were allowed to cool at room temperature.

The distillation step started with the addition of $30 \mathrm{~mL}$ of distilled water to the digested samples. The contents of the tubes was homogenized, the $\mathrm{pH}$ was raised using sodium hydroxide solution $(50 \%(\mathrm{~m} / \mathrm{v}))$, and flasks were placed in the Kjeldahl distillation equipment. An Erlenmeyer flasks containing $25 \mathrm{~mL}$ a of boric acid indicator solution $(4 \%(\mathrm{~m} / \mathrm{v}))$ was placed at the other end of the distiller. The digested system was distilled until the distillate started to turn green.

The distillate was titrated with standard solution of hydrochloric acid $\left(0.01 \mathrm{~mol} \mathrm{~L}^{-1}\right)$ to a until the color change. Protein content was calculated using Equations (6) and (7):

\%Nitrogen compounds $=\frac{\text { F } \times 0.0014 \times 100 \times V \times M}{\mathrm{~m}}$

$\%$ Protein $=\%$ Nitrogen compounds $\times$ NF

Where $\mathrm{F}$ is the correction factor for the standard solution of hydrochloric acid $\left(0.01 \mathrm{~mol} \mathrm{~L}^{-1}\right), V$ is the volume of titrant that was necessary to reach the titration endpoint, $M$ is the molarity of the titrant, NF is the conversion factor used to estimate protein content from

measured nitrogen content, and $m$ is the mass of the sample.

\subsection{Crude fat determination}

Crude fat was determined by Soxhlet extraction according to the AOAC method (1995). First, $2.5 \mathrm{~g}$ of sample was placed in a round-bottom flask containing $190 \mathrm{~mL}$ of petroleum ether. The sytem was exhaustively extracted for $6 \mathrm{~h}$ at $60 \pm 2$ ${ }^{\circ} \mathrm{C}$. The solvent was evaporated and stored, and the sample was oven dried at $80 \pm 2{ }^{\circ} \mathrm{C}$ for $8 \mathrm{~h}$ to ensure complete removal of residual solvent. The flask was allowed to cool to room temperature, in desiccator containing desiccant, and determined mass. The percentage of crude fat was calculated according to Equation (8): 
WFat $=\frac{\text { Sample mass before extraction-Sample mass after extraction }}{\text { Sample mass before extraction }} \times 100$

\section{Results and discussion}

\subsection{Particle size distribution}

The particle size distribution of biomass grinds is shown in Figure 2. Note that rice straw bran and sugarcane bagasse exhibited a more uniform particle size distribution. Most of the rice straw bran sample was retained in no. 35 sieve; that is, the particles had a diameter of less than $420 \mu \mathrm{m}$. The sugarcane bagasse sample was mainly retained in no. 10 sieve (1.68 mm). Corn peel bran showed a non-uniform particle size distribution. About $42 \%$ of the sample was retained in no 35 sieve (420 $\mu \mathrm{m})$.

Figure 2 - Particle size distribution of sugarcane bagasse, rice straw bran and corn peel bran, respectively.

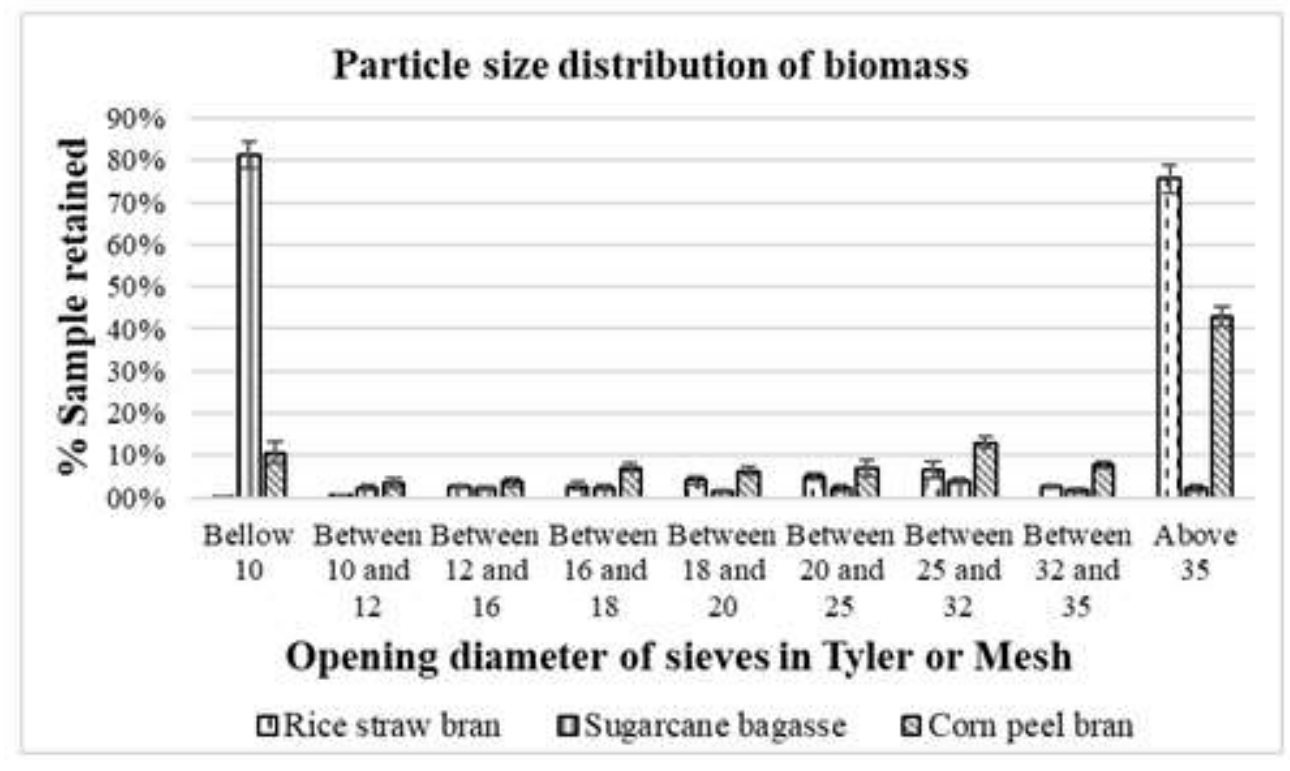

Source: Authors.

Particle size directly affects the contact area between reagents and biomass, and can influence later processes, enzymatic saccharification and microbial fermentation, in the production of lignocellulosic ethanol.

\subsection{Chemical Characteristics}

Table 1 shows the chemical composition of the studied residues, extractives, cellulose, hemicellulose, lignin, and ashes. The removal of non-structural material from biomass is important to avoid interference in later analytical steps. The sugarcane bagasse and corn peel bran, greater extractive content, 18.70 and $12.82 \%$ respectively, when compared with the rice straw bran $(12.82 \%)$, the results are in accordance with the characteristics of residues characterized and those obtained by other authors (Table 2). 
Table 1 - Chemical characterization of biomass to produce second generation ethanol.

\begin{tabular}{lccccc}
\hline & & Cellulose & Hemicellulose & Lignin & Ashes \\
& Extratives $(\%)$ & $(\%)$ & $(\%)$ & $(\%)$ & $(\%)$ \\
\cline { 2 - 6 } Rice Straw Bran & $5.82 \pm 2.73$ & $38.33 \pm 0.96$ & $19.73 \pm 0.96$ & $19.01 \pm 0.83$ & $7.99 \pm 0.17$ \\
Sugarcane bagasse & $36.40 \pm 1.83$ & $31.09 \pm 2.99$ & $28.61 \pm 2.99$ & $12.30 \pm 1.34$ & $2.70 \pm 0.06$ \\
Corn Peel Bran & $12.82 \pm 0.06$ & $55.75 \pm 2.40$ & $12.93 \pm 2.40$ & $9.84 \pm 0.22$ & $3.47 \pm 0.17$ \\
\hline
\end{tabular}

Source: Authors.

Table 2 - Extratives compositions in \% of biomass.

\begin{tabular}{ccc}
\hline & Extratives (\%) & Ref. \\
\cline { 2 - 3 } Rice husk & 3.10 & Morais et. al., 2010 \\
Rice husk & 4.08 & Mourtzinis et. al., 2016 \\
Sugarcane bagasse & 31.76 & Narron et. al., 2017 \\
Corn Straw & 11.60 & Ogeda and Petri, 2010 \\
Corn cob & 18.00 & Ogeda and Petri, 2010 \\
Corn Straw & 17.22 & Panaro et. al., 2015 \\
\hline
\end{tabular}

Source: Authors.

The cellulose content (Table 1) of rice straw bran (38.33\%) and sugarcane bagasse (27.09\%) were similar to those reported in the literature (Table 3). Cellulose content in corn peel bran (55.75\%), however, was higher than that found in other studies for corn straw and cob. No data on the cellulose content of corn peel bran were found in the literature, as this residue, obtained from starch production, is used principally as animal feed.

Table 3 - Cellulose, hemicellulose and lignin composition in \% of biomass.

\begin{tabular}{ccccc}
\hline & Cellulose & Hemicellulose & Lignin & Ref. \\
& $(\%)$ & $(\%)$ & $(\%)$ & Prasara and Gheewala, 2017 \\
Rice straw & $29.20-34.70$ & $23.00-25.90$ & $17.00-19.00$ & Raele et. al., 2014 \\
Rice straw & 44.00 & 20.10 & 19.00 & Rastogi and Shrivastava, 2017 \\
Rice straw & 42.54 & 24.51 & 9.16 & Santos et. al., 2010 \\
Sugarcane bagasse & 38.80 & 29.40 & 21.70 & Sasaki et al., 2016 \\
Sugarcane bagasse & 46.86 & 27.50 & 26.70 & Prasara and Gheewala, 2017 \\
Sugarcane bagasse & $25.00-45.00$ & $28.00-32.00$ & $15.00-25.00$ & Morais et. al., 2010 \\
Corn Straw & 36.70 & 34.20 & 14.00 & Morais et. al., 2010 \\
Corn cob & 35.40 & 26.90 & 18.00 & Silva et. al., 2015 \\
Corn Straw & 41.18 & 16.31 & 14.14 & Panaro et. al., 2015 \\
Corn Straw & 47.22 & 22.15 & 12.77 & \\
\hline
\end{tabular}

Source: Authors.

A biomass with high cellulose content presents potential feedstock for bioethanol production, just as delignification is essential to increase the yield of enzymatic hydrolysis and alcoholic fermentation (Abraham et al., 2016; Cai et al., 2016; Silva 
et al., 2015). The results obtained suggest that biomass evaluated in the present study can be satisfactorily used as raw materials for the production of second-generation ethanol, because of their high cellulose and hemicellulose contents.

The biomass samples had a low concentration of ash, similar to that of other biomass samples reported in the literature (Table 4). A low ash content is desirable for biomass conversion to bioethanol and application in energy generation systems (Filho and Juliani, 2013).

Table 4 - Ashes composition in \% of biomass.

\begin{tabular}{ccc}
\hline & Ashes (\%) & Ref. \\
\cline { 2 - 3 } Rice husk & 17 & Morais et al., 2010 \\
Sugarcane bagasse & 5.1 & Santos et al., 2012 \\
& 1.61 & Sasaki et. al., 2016 \\
Corn Straw & 2.3 & Silva et al., 2015 \\
& 0.64 & Panaro et. al., 2015 \\
\hline
\end{tabular}

Source: Authors.

The ashes lower content may be considered an advantage, because during the pretreatment the biomass containing salts solubilize in the hemicellulose and cellulose hydrolysates. This increase in the concentration of ions leads to an increase in the osmotic pressure in the medium, hindering the alcoholic fermentation (Silva et al., 2015).

\subsection{Carbohydrate Composition}

The carbohydrate composition of rice straw bran, sugarcane bagasse, and corn peel bran is presented in Table 5. The presence of glucose and xylose indicates that cellulose and hemicellulose were degraded during delignification (Islam et al., 2017; Lee et al., 2017).

Table 5 - Monosaccharide concentration resulting from hydrolysis.

\begin{tabular}{lccc}
\hline & Rice Straw Bran (\%) & Sugarcane bagasse (\%) & Corn Peel Bran (\%) \\
\cline { 2 - 4 } Glucose & $40.69 \pm 1.60$ & $43.35 \pm 4.00$ & $51.58 \pm 1.60$ \\
Fructose & $5.35 \pm 0,70$ & $6.84 \pm 0.20$ & $8.59 \pm 0.70$ \\
Xylose & $4.94 \pm 0.10$ & $6.84 \pm 0.20$ & $8.59 \pm 0.70$ \\
Arabinose & $3.35 \pm 0.00$ & - & $4.43 \pm 0.30$ \\
Saccharose & - & $1.45 \pm 0.10$ & - \\
Cellobiose & - & $1.30 \pm 0.09$ & - \\
\hline
\end{tabular}

Source: Authors.

Table 6 shows that the carbohydrate composition of the studied residues was similar to that of other samples reported in the literature. Some monosaccharides, mostly pentoses, are more difficult to ferment to fuel ethanol than hexoses such as glucose (Vassilev et al., 2010). The physicochemical characterization of these residues suggests that they can be submitted to enzymatic or chemical hydrolysis for the release of sugars and subsequent fermentation for biofuel production. 
Table 6 - Carbohydrate Composition in \% of monosaccharides.

\begin{tabular}{lccccc}
\hline & Glucose & Xylose & Arabinose & Cellobiose & Ref. \\
\cline { 2 - 6 } Rice straw & 32.83 & 12.50 & 7.35 & - & Sudha et al., 2015 \\
& 34.20 & 19.30 & 2.00 & - & Szczerbowski et al., 2014 \\
Sugarcane bagasse & 36.74 & 20.30 & 1.80 & - & Vieira et. al., 2013 \\
& 42.30 & 20.90 & - & - & Zambom et. al., 2008 \\
Corn free of extractives & 42.60 & 25.80 & 13.70 & - & Zheng et al., 2017 \\
Corn & 45.40 & 22.70 & 2.30 & - & Zheng et al., 2017 \\
Corn cob & 37.90 & 29.00 & 2.80 & - & Zheng et al., 2017 \\
\hline
\end{tabular}

Source: Authors.

\subsection{Total Solids, Moisture Content, and Water Activity}

The total solids, moisture content, and water activity of the biomass samples are presented in Table 7. These parameters are directly associated with microbial development (Romão, 2015) and can indicate the chemical, physical, and microbial stability of the biomass (Cavalcante et al., 2018). Different microorganisms require different values of $\mathrm{a}_{\mathrm{w}}$ (which ranges from 0 to 1 ) for growth. Fungi can grow at an $\mathrm{a}_{\mathrm{w}}$ of 0.70 , yeasts at 0.80 , and bacteria at 0.90 . Microbial development is unlikely at $\mathrm{a}_{\mathrm{w}}$ values of $0.20-0.50$ (Morais et al., 2010).

Table 7 - Quantity of total Solids, Moisture and Water Activity (Aw) in biomass.

\begin{tabular}{lccc}
\hline & Total Solids (\%) & Moisture (\%) & Aw \\
\cline { 2 - 4 } Rice Straw Bran & $93.08 \pm 2.15$ & $6.92 \pm 2.15$ & $0.391 \pm 0.05$ \\
Sugarcane bagasse & $57.29 \pm 3.88$ & $42.71 \pm 3.88$ & $0.822 \pm 0.03$ \\
Corn Peel Bran & $90.91 \pm 1.43$ & $9.09 \pm 1.43$ & $0.437 \pm 0.03$ \\
\hline
\end{tabular}

Source: Authors.

The residue composition and the pre-treatment used can influence the moisture content of a biomass. Vieira et al. (2013) reported that the moisture content of rice husks was 7.9-10\% and of corn cob was 16.93\%. Sugarcane bagasse has a moisture content of around 50\% (Manochio et al., 2017). In this study, the moisture contents of the samples were lower than those presented in the literature. These results do study indicate important information about properties, storage and handling criteria for biomass.

\subsection{Crude Fat and Protein Contents}

Crude fat and protein contents are presented in Table 8. The results of this study were similar to those reported by other authors. Moongngarm et al. (2012) found a crude fat content of $17.59 \%$ in rice bran. A crude fat content of $15.3 \%$ was observed in brown rice straw bran in a study by Chaud et al. (2009). Carvalho et al. (2006) characterized sugarcane bagasse and found a crude fat content of $0.07 \%$. Zambom et al. (2008) reported that ground corn had a crude fat content of 3.59\%. 
Table 8 - Composition of Fat and Protein in biomass.

\begin{tabular}{lcc}
\hline & Fat (\%) & Protein (\%) \\
\cline { 2 - 3 } Rice Straw Bran & $17.45 \pm 3.43$ & $0.68 \pm 0.04$ \\
Sugarcane bagasse & $0.59 \pm 0.14$ & - \\
Corn Peel Bran & $3.32 \pm 0.13$ & $7.31 \pm 0.03$ \\
\hline
\end{tabular}

Source: Authors.

The protein content of sugarcane bagasse was also similar to that reported in other studies. Carvalho et al. (2006) observed a protein content of $2.32 \%$ in sugarcane bagasse. Zambom et al. (2008) studied the composition of ground corn and observed a crude protein content of $8.38 \%$, similar to that of corn peel bran in the present study. Kunrath et al. (2010) found a protein content of $15.5 \%$ in rice straw bran, similar to our results. However, Chaud et al. (2009) reported a protein content of $1.54 \%$ in rice straw bran. This difference can be due to the type of rice evaluated, the climatic and soil conditions in which the rice was grown, and the time of harvest.

\section{Conclusions}

The physicochemical characteristics of agro-industrial residues can determine their suitability for application in value adding processes. Provides important information such as biomass properties, theoretical yields and issues related to large scale industrial operations. The results of this study suggest that rice straw bran, sugarcane bagasse, and corn peel bran are potential feedstocks for the production of second-generation ethanol, because of their high cellulose and hemicellulose levels and a significant amount of monosaccharides, mainly glucose and xylose, released after hydrolysis. Brazil's large agroindustrial sector can benefit greatly from using these residues for bioethanol production, in the management of waste, enabling applications and valuing agro-industrial by-products.

In future studies and research, it is suggested to use agroindustry biomasses characterized in the production of enzymes and as a substrate for cellulosic ethanol production.

\section{Acknowledgements}

This study was supported by the Minas Gerais State Research Foundation, Brazil (FAPEMIG), under project code FAPEMIG (TEC- APQ- 02489-16 e TEC-APQ-02079-16). The authors are also gratefully to the Cane Technology Centre (CTC), Brazil, and cereal and food processing industries, Brazil.

\section{References}

AOAC international. Official methods of analysis of AOAC International. (1995). (16th ed.), AOAC International. Abraham, A., Mathew, A. K., Sindhu, R., Pandey, A., \& Binod, P. (2016). Potential of rice bio-refining: An overview. Bioresource Technology, 215, 29-36.

Bahmani, M. A., Shafiei, M., Karimi, K. (2016). Anaerobic digestion as a pretreatment to enhance ethanol yield from lignocelluloses. Process Biochemistry, $51(9), 1256-1263$.

Cai, P. L., Luo, Z., Qin, P., Chen, C., Wang, Y., Zhang C., Wang, Z., \& Tan, T. (2016). Effect of acid pretreatment on different parts of corn stalk for second generation ethanol production. Bioresource Technology, 206, 86-92.

Carvalho, G. G. P., Pires, A. J. V., Veloso, C. M., Magalhães, A. F., Freire, M. A. L., Silva, F. F., Silva, R. R., Carvalho, B. M. A. (2006). Valor nutritivo do bagaço de cana-de-açúcar amonizado com quatro doses de uréia. Pesquisa Agropecuária Brasileira, 41 (1), $125-132$.

Cavalcante, C. E. B., Rodrigues, S., Afonso, M. R. A., \& Costa, J. M. C. (2018). Comportamento higroscópico da polpa de graviola em pó obtida por secagem em spray dryer. Brazilian Journal of Food Technology, 21 e 2017121.

Chaud, L. C. S., Arruda, P. V., \& Felipe, M. G. A. (2009). Potencial do farelo de arroz para utilização em bioprocessos. Revista Científica da Fundação Educacional de Ituverava, 6 (2). 
Filho, S. R., \& Juliani, A. J. (2013). Sustentabilidade da produção de etanol de cana-de-açúcar no Estado de São Paulo. Estudos Avançados, 27 (78), $195-212$.

Gombert, A. K., \& Maris, A. J. (2015). Improving conversion yield of fermentable sugars into fuel ethanol in 1st generation yeast-based production processes. Current Opinion Biotechnology, 33, 81-86.

Gomide, R. Operações Unitárias. (1997). Edição do Autor.

Hames, B., Scarlata, C., \& Sluiter, A. (2008). Determination of protein content in biomass. Golden Colorado: National Renewable Energy Laboratory. Technical Report. NREL/TP-510-42625. https://www.nrel.gov/docs/gen/fy08/42625.pdf

Islam, M. S., Kao, N., Bhattacharyam, S. N., Gupta, R., \& Bhattacharjee, P. K. (2017). Effect of low pressure alkaline delignification process on the production of nanocrystalline cellulose from rice husk. Journal of the Taiwan Institute of Chemical Engineers, 80, 820-834.

Jan, K., Riar, C. S., \& Saxena, D. C. (2017). Characterization of agro-industrial byproducts and wastes for sustainable industrial application. Journal of Food Measurement and Characterization, 11, 1254-1265.

Kunrath, M. A., Kessler, A. M., Ribeiro, A. M. L., Vieira, M. M., Silva, G. L., \& Peixoto, F. D. (2010). Evaluation methodologies of nutritional value of defatted rice bran for swine. Pesquisa Agropecuária Brasileira, 45, 1172-1179.

Lee, J., Vadlani, P. V., \& Faubion, J. (2017). Corn bran bioprocessing: Development of an integrated process for microbial lipids production. Bioresource Technology, 243, 196-203.

Manochio, C., Andrade, B. R., Rodriguez, R. P., \& Moraes, B. S. (2017). Ethanol from biomass: A comparative overview. Renewable and Sustainable Energy Reviews, 80, 743-755.

Mitra, J., Shrivastava, S. L., \& Srinivasa, R. (2015). Characterization of vacuum dried onion slices. Journal of Food Measurement and Characterization, 9, 1-10.

Moongngarm, M., Daomukda, N., \& Khumpika, S. (2012). Chemical Compositions, Phytochemicals, and Antioxidant Capacity of Rice Bran, Rice Bran Layer, and Rice Germ. APCBEE Procedia, 2, 73 - 79. https://doi.org/10.1016/j.apcbee.2012.06.014.

Morais, J. P. S., Rosa, M. F., \& Marconcini, J. M. (2010). Procedimentos para análise lignocelulósica. Documentos 236. Campina Grande: Embrapa Algodão. https://www.infoteca.cnptia.embrapa.br/bitstream/doc/883400/1/DOC236.pdf.

Mourtzinis, S., Cantrell, K. B., Arriaga, F. J., Balkcom, K. S., Novak, J. M., Frederick, J. R., \& Karlen D. L. (2016). Carbohydrate and nutrient composition of corn stover from three southeastern USA locations. Biomass and Bioenergy, 85, 153-158.

Narron, R. H., Han, Q., Park, S., Chang, H., \& Jameel, H. (2017). Lignocentric analysis of a carbohydrate-producing lignocellulosic biorefinery process. Bioresource Technology, 241, 857-867.

OECD/FAO (2016), OECD-FAO Agricultural Outlook 2016-2025, OECD Publishing, Paris. http://dx.doi.org/10.1787/agr_outlook-2016-en.

Ordoñez, J. A. et al (2005). Tecnologia de alimentos: componentes dos alimentos e processos. Artmed.

Panaro, M. S., de Barros, R. R. O., Teixeira, R. S. S., \& Bon, E. P. S. (2015). Pré-tratamento de biomassa de cana-de-açúcar por moinho de bolas em meios seco, úmido e na presença de aditivos. Blucher Chemical Engineering Proceedings, 1 (1).

Paula, L. E. R., Trugilho, P. F. Napoli, A., \& Bianchi, M. L. (2011). Characterization of residues from plant biomass for use in energy generation. Cerne, 17, 237-246.

Pereira, A. S. et al. (2018). Metodologia da pesquisa científica. UFSM.https://repositorio.ufsm.br/bitstream/handle/1/15824/Lic_Computacao_MetodologiaPesquisa-Cientifica.pdf?sequence=.

Prasara-A, J., \& Gheewala, S. (2017). Sustainable utilization of rice husk ash from power plants: A review. Journal of Cleaner Production, 167, $1020-1028$.

Raele, R., Boaventura, J. M.G., Fischmann, A. A., \& Sarturi, G. (2014). Scenarios for the second generation ethanol in Brazil. Technological Forecasting \& Social Change, 87, 205-223.

Ranby B. G. (1952). The Physical Characteristics of Alpha-, Beta- and Gamma-Cellulose, Tappi method, Sven. Papperstidn, 55, 115-124.

Rastogi, M., \& Shrivastava, S. (2017). Recent advances in second generation bioethanol production: An insight to pretreatment, saccharification and fermentation process. Renewable and Sustainable Energy Reviews, 80, 330-340.

Romão, D. R. Potencial de Fibras de resíduo agrícola: palha de milho (Zea mays L.) para a produção de celulose (2015). Universidade de Brasília, Faculdade de Tecnologia, Departamento de Engenharia Florestal. Available from:

Santos, F. A., Queiróz, J. H., Colodette, J. L., Fernandes, S. A., Guimarães, V. M., \& Rezende, S. T. (2012). Potential of sugarcane straw for ethanol production. Química Nova, 35, 1004-1010.

Sasaki, K., Okamoto, M., Shirai, T., Tsuge, Y., Fujino, A., Sasaki, D., Morita, M., Matsuda, F., Kikuchi, J., \& Kondo, A. (2016). Toward the complete utilization of rice straw: Methane fermentation and lignin recovery by a combinational process involving mechanical milling, supporting material and nanofiltration. Bioresource Technology, 216, 830-837.

Silva, C. F. L., Schirmer, M. A., Maeda, R. N., \& Barcelos, C. A. (2015). Potential of giant reed (Arundo donax L.) for second generation ethanol production. Electronic Journal of Biotechnology, 18, 10-15. 
Research, Society and Development, v. 10, n. 8, e33110817151, 2021

(CC BY 4.0) | ISSN 2525-3409 | DOI: http://dx.doi.org/10.33448/rsd-v10i8.17151

Sluiter, A., Ruiz, R., Scarlata, C., Sluiter, J., \& Templeton, D. (2008a). Determination of extractives in biomass. Golden, Colorado: National Renewable Energy Laboratory. Technical Report. NREL/TP-510-42619. https://www.nrel.gov/docs/gen/fy08/42619.pdf

Sluiter, A., Hames, B., Hyman, D., Payne, C., Ruiz, R., Scarlata, Sluiter, J., Templeton, D., \& Wolfe, J. (2008b). Determination of total solids in biomass and total dissolved solids in liquid process samples. Golden, Colorado: National Renewable Energy Laboratory. Technical Report. NREL/TP-510-42621.

Sluiter, A., Hames, B., Ruiz, R., Scarlata, C., Sluiter, J., \& Templeton, D. (2008c). Determination of ash in biomass. Golden, Colorado: National Renewable Energy Laboratory. Technical Report. NREL/TP-510-42622.

Sluiter, A., Hames, B., Ruiz, R., Scarlata, C., Sluiter, J., Templeton, D., \& Crocker, D. (2012). Determination of structural carbohydrates and lignin in biomass. Golden, Colorado: National Renewable Energy Laboratory. Technical Report. NREL/TP-510-42618. https://www.nrel.gov/docs/gen/fy13/42618.pdf

Sudha, M. L., Indumathi, K., Sumanth, M. S. S. Rajarathnam, S., \& Shashirekha, M. N. (2015). Mango pulp fibre waste: characterization and utilization as a bakery product ingredient. Journal of Food Measurement and Characterization, 9, 381-388.

Szczerbowski, D., Pitarelo, A .P., Filho, A. Z., \& Ramos, L. P. (2014). Sugarcane biomass for biorefineries: Comparative composition of carbohydrate and non-carbohydrate components of bagasse and straw. Carbohydrate Polymers, 114, 95-101.

UDOP. União dos Produtores de bioenergia. (2017). Available from: http://www.udop.com.br/index.php?item=noticias\&cod=1154751.

USDA. United States Department of Agriculture (2020). Brazil: Biofuels Annual. Available from: https://www.fas.usda.gov/data/brazil-biofuels-annual-7.

Vassilev, S. V., Baxter, D., Andersen, L. K., \& Vassileva, C. G. (2010). An overview of the chemical composition of biomass. Fuel, 89, 913-933.

Vieira, A. C., de Souza, S. N. M., Bariccatti, R. A., Siqueira, J. A. C., \& Nogueira, C. E. C. (2013). Caracterização da casca de arroz para geração de energia. Revista Varia Scientia Agrárias, 3, 51-57.

Zambom, M.A., Alcalde, C. R., da Silva, K. T., Macedo, F. A. F., Ramos, C. C. O., \& Passianoto, G. O. (2008). Performance and nutrients digestibility of rations with soybean hulls as a corn ground replacement for Saanen goats, in prepartum and lactation. Revista Brasileira de Zootecnia, 37, 1311-1318.

Zheng, W., Zheng, Q., Xue, Y., Hu, J., \& Gao, M. (2017). Influence of rice straw polyphenols on cellulase production by Trichoderma reesei. Journal of Bioscience and Bioengineering, 123, 731-738.

Ziaie-shirkolaee, Y., Mohammadi-Rovshandeh, J., Charani, P. R., \& Khajeheian, M. B. (2007). Study on cellulose degradation during organosolv delignification of wheat straw and evaluation of pulp properties. Iranian Polymer Journal, 16 (2), 83-96. 